\title{
The Hazard Content of Cadmium, Lead, and Other Trace Elements in Some Medicinal Herbs and Their Water Infusions
}

\author{
Fuad A. Ababneh ${ }^{1,2}$ \\ ${ }^{1}$ Chemistry Department, College of Science, Al-Hussein Bin Talal University, Ma'an, Jordan \\ ${ }^{2}$ Chemistry Department, College of Science, Al Imam Mohammad Ibn Saud Islamic University (IMSIU), \\ P.O. Box 90950, Riyadh 11623, Saudi Arabia
}

Correspondence should be addressed to Fuad A. Ababneh; ababneh.f@gmail.com

Received 7 May 2017; Accepted 13 September 2017; Published 19 October 2017

Academic Editor: Adil Denizli

Copyright (C) 2017 Fuad A. Ababneh. This is an open access article distributed under the Creative Commons Attribution License, which permits unrestricted use, distribution, and reproduction in any medium, provided the original work is properly cited.

\begin{abstract}
54 samples belonging to 23 herbal species (15 individuals and 8 mixtures) were analyzed for their contents of heavy metals in the raw materials and in their water infusions. Trace and toxic elements in these samples were determined by using inductively coupled plasma-atomic emission spectrometry (ICP-OES) following acid digestion. The order of decreasing mean metal concentrations in raw materials $(\mathrm{mg} / \mathrm{kg})$ was found to be as follows: $\mathrm{Fe}(440)>\mathrm{Mn}(162)>\mathrm{Zn}(45.8)>\mathrm{Cu}(12)>\mathrm{Pb}(10.4)>\mathrm{Ni}(5.4)>\mathrm{Cr}(2.9)>\mathrm{Co}$ $(0.91)>\mathrm{Cd}(0.5)$. It was found that $21 \%$ of the analyzed samples contain both $\mathrm{Cd}$ and $\mathrm{Pb}$ above their permissible limits. However, the infusions produced from these plants were found to contain fewer amounts of metals than the raw materials. Studied metals had the following mass transfer percentages to the infusion solutions (Fe: 3.5\%, Cd: 14\%, Cr: 15\%, Pb: 20\%, Co: 29\%, Ni: 31\%, Zn: $36 \%$, Cu: $48 \%$, and $\mathrm{Mn}: 53 \%$ ). The estimated daily intake calculated for the toxic elements $\mathrm{Pb}$ and Cd through the consumption of herbal infusions was far below the tolerable daily intake set by the World Health Organization (WHO).
\end{abstract}

\section{Introduction}

Medicinal plants and their various products (raw material, mixtures, distillates, extracts, etc.) are well known as herbal medicines; they have been available for many hundreds of years for treatment of human diseases. Nowadays, various species of herbs are widely used as raw materials in the pharmaceutical industries and also extensively consumed as home remedies [1]. Recently, the use of herbal medicines has greatly increased due to mainly the common belief that the herbal remedies are of natural origin and hence inherently safe and without any adverse health effects compared to synthetic medicines. Indeed, this belief is groundless; poisonings associated with the presence of heavy toxic metals in medicinal plants and food were reported regularly [2-4]. Other aspects may encourage the use of herbal remedies such as the availability of herbal medicines without medical prescription, their reasonable low prices, and the fail of synthetic drugs to cure some human diseases $[5,6]$.

The increasing popularity of herbal products as medications has produced fear about their quality and safety for human consumption. These products may be contaminated with microbial contaminants, chlorinated pesticides, heavy metals, and other chemical toxins $[7,8]$. The major sources of metal contamination in herbal products are agricultural activities, mining and smelting industries, rainfall, water and air pollution, soil contamination, and the use of fossil fuels for heating [9]. Metals such as zinc, iron, manganese, and copper are essential elements since they play an important role in biological systems and only become harmful at high concentrations, whereas mercury, lead, and cadmium are nonessential elements as they are toxic, even at low concentration levels [10].

The growing condition of plant, chemical treatments, type of plant species, processing steps, and storage condition are important factors affecting the levels of different metals in herbal preparations [11]. Previous studies showed that some toxic elements were detected in various herbal plants at different concentrations [12-14]. For example, the total arsenic, cadmium, and lead were found in chamomile at concentration ranges of $82-124 \mu \mathrm{g} / \mathrm{kg}, 184-256 \mu \mathrm{g} / \mathrm{kg}$, and $288-1625 \mu \mathrm{g} / \mathrm{kg}$, respectively [12]. However, in thyme, arsenic 
and cadmium were found at lower concentrations ranges as $28-67 \mu \mathrm{g} / \mathrm{kg}$ and $143-268 \mu \mathrm{g} / \mathrm{kg}$, respectively, whereas $\mathrm{Pb}$ was found at high elevated concentrations with a range of $6452-8633 \mu \mathrm{g} / \mathrm{kg}$ [12]. The herbal content of the toxic elements only is an indication of the toxicity of these products because of the toxicity affected by the method of exposure. Hence, taking the herbal remedies as an oral drug (consumption as food) will result in the digestion of these products in stomach while taking these products as beverage or as herbal teas means that some of the metals will be extracted to the infusion solution. In this work, the total metal contents and the extracted (fusion) fraction of various herbal preparations will be determined and evaluated for their toxicity.

\section{Materials and Methods}

2.1. Reagents and Materials. All solutions were prepared with analytical reagent grade chemicals. Deionized water with specific resistivity of $18.0 \mathrm{M} \Omega \mathrm{cm}^{-1}$ was used. All glassware used in the present study was previously soaked in $10 \%(\mathrm{v} / \mathrm{v})$ $\mathrm{HNO}_{3}$ solution for $12 \mathrm{~h}$ and rinsed with deionized water. Nitric acid $\left(\mathrm{HNO}_{3}, 69 \%\right)$ and hydrogen peroxide $\left(\mathrm{H}_{2} \mathrm{O}_{2}\right.$, $30 \%$ ) were of ultrapure quality (Trace SELECTâ, Fluka). Standard calibration of mixed and individual metal solutions of $\mathrm{Fe}, \mathrm{Zn}, \mathrm{Cu}, \mathrm{Cr}, \mathrm{Ni}, \mathrm{Mn}, \mathrm{Co}, \mathrm{Pb}$, and $\mathrm{Cd}$ (BDH Spectrosol ${ }^{\circledR}$, Fluka Chemika ${ }^{\circledR}$ ) at concentration of $1000 \mathrm{mg} \mathrm{L}^{-1}$ was appropriately diluted and used to calibrate the ICP-OES before metal determination. A certified reference materials (NIST 1570a), spinach leave, obtained from National Institute of Standards and Technology, USA, was used for method validation.

2.2. Sampling and Analysis. A total of 54 samples of various commercially available medicinal herbs were randomly purchased from general stores in Irbid city, Jordan. The herbal samples were commercially available in the form of tea bags packaged in boxes with $12-24$ pieces of tea bags; each bag contains $1.1-2.7 \mathrm{~g}$ of the herbs raw material. The raw herbal material from all tea bags in one box was placed in polyethylene container, mixed, homogenized, and stored at room temperature. Brand codes, contents, and other information are presented in Table 1.

Aliquots (1-2 g) of the herbal raw material were accurately weighed into a precleaned glass beaker and digested with $15 \mathrm{ml}$ of a mixture of freshly prepared solution of $(1: 1)(\mathrm{v} / \mathrm{v})$ $\mathrm{HNO}_{3}(69 \%)-\mathrm{H}_{2} \mathrm{O}_{2}(30 \%)$. Each beaker was covered with a watch glass and heated on hot plate at $150-180^{\circ} \mathrm{C}$; aliquots of nitric acid were added until the solutions were clear. Solutions were contentiously boiled until the volume for each sample reduced to about $5 \mathrm{ml}$. The solutions were then allowed to cool, filtered (glass wool), and diluted up to $50 \mathrm{ml}$ with acidified $\left(\mathrm{HNO}_{3}\right)$ deionized water and then placed in acid washed $60 \mathrm{ml}$ polyethylene bottles.

The herbal infusions were prepared by adding $200 \mathrm{ml}$ of hot $\left(97^{\circ} \mathrm{C}\right)$ Milli-Q water to a weighed portion $(2 \mathrm{~g})$ of plant material. The suspension was then stirred with a glassrod stirrer for 1 minute and steeped for a total of $10 \mathrm{~min}$, as recommended by the manufacturers. The 10-minute infusion time was found to be adequate to prepare a good quality tea beverage [15]. Subsequently, the steeped infusion was filtered and then acidified with $\mathrm{HNO}_{3}$ and evaporated to $100 \mathrm{ml}$.

All digested samples and infusions were analyzed, in triplicate, for metal contents using Inductively Coupled Plasma Optical Emission Spectrometry (ICP-OES) (VISTAMPX instrument). The simultaneous ICP-OES was equipped with axial vision, a radio frequency (RF) source of $30 \mathrm{MHz}$, a CCD (Charge Coupled Device), a peristaltic pump, and a glass concentric nebulizer.

2.3. Quality Control. In order to validate the instrumental methods and analytical procedures for accuracy, all the samples were taken in triplicate and all measurements were run in triplicate for standards and samples. Analytical blank involving all reagents was run (in triplicate) to check for interferences and cross-contamination of every batch of 15 samples. Certified reference material (NIST 1570a) was also analyzed every batch. Accuracy was determined by comparing the measured concentrations with the certified values and was expressed as a percentage recovery (\% recov.). The achieved results were in good agreement with certified values. The results are given in Table 2.

\section{Results}

3.1. Mineral Contents of Herbal Raw Materials. The concentrations of $\mathrm{Fe}, \mathrm{Cu}, \mathrm{Zn}, \mathrm{Mn}, \mathrm{Cr}, \mathrm{Co}, \mathrm{Ni}, \mathrm{Cd}$, and $\mathrm{Pb}$ elements in 54 samples of individuals and mixtures of medicinal herbal plants were determined by using ICP-OES. The mean metals concentrations in raw herbal materials are listed in Table 3. It was observed that all medicinal herbs contain significant amounts of metals with a very wide variability in their concentrations. The order of decreasing mean total concentrations for these metals was $\mathrm{Fe}>\mathrm{Mn}>\mathrm{Zn}>\mathrm{Cu}>\mathrm{Pb}$ $>\mathrm{Ni}>\mathrm{Cr}>\mathrm{Co}>\mathrm{Cd}$. Similar trend $(\mathrm{Fe}>\mathrm{Sr}>\mathrm{Mn}>\mathrm{Zn}>\mathrm{Rb}>$ $\mathrm{Cu}>\mathrm{Ni}>\mathrm{Cr}>\mathrm{Co}>\mathrm{Pb}$ ) was reported by another work [16]. It was observed that $\mathrm{Fe}, \mathrm{Mn}, \mathrm{Zn}, \mathrm{Cu}$, and $\mathrm{Ni}$ were detected in all of the analyzed herbal samples (100\%). Chromium and lead were detected in $87 \%$ and $81 \%$ of the analyzed samples, respectively. The least detected elements were cadmium and cobalt; they were found in $65 \%$ and $54 \%$ of the analyzed samples.

3.2. Mineral Contents of Herbal Infusion. The results for the mean concentrations of studied metals in herbal infusions are presented in Table 4 . The mass percentage of metal transported from the raw material to the infusion solution was found to be metal dependent. Iron was found to be the least metal transported from herbs raw material to the infusion solutions; in most cases, less than $10 \%$ of total iron in raw material was transported to the infusion solutions with an average of $3.5 \%$ for all the analyzed samples. Mn, on the other hand, was found to be the most transported metal to the infusions with an average of $53 \%$. Other metals had the following percentages of mass transfer (Cd: 14\%, Cr: 15\%, Pb: 20\%, Co: 29\%, Ni: 31\%, Zn: $36 \%$, and $\mathrm{Cu}: 48 \%$ ). The correlation between the total metal concentration in raw material and its concentration in the infusion solution (labile fraction) was studied; the results are shown in Figures 1 and 2. 


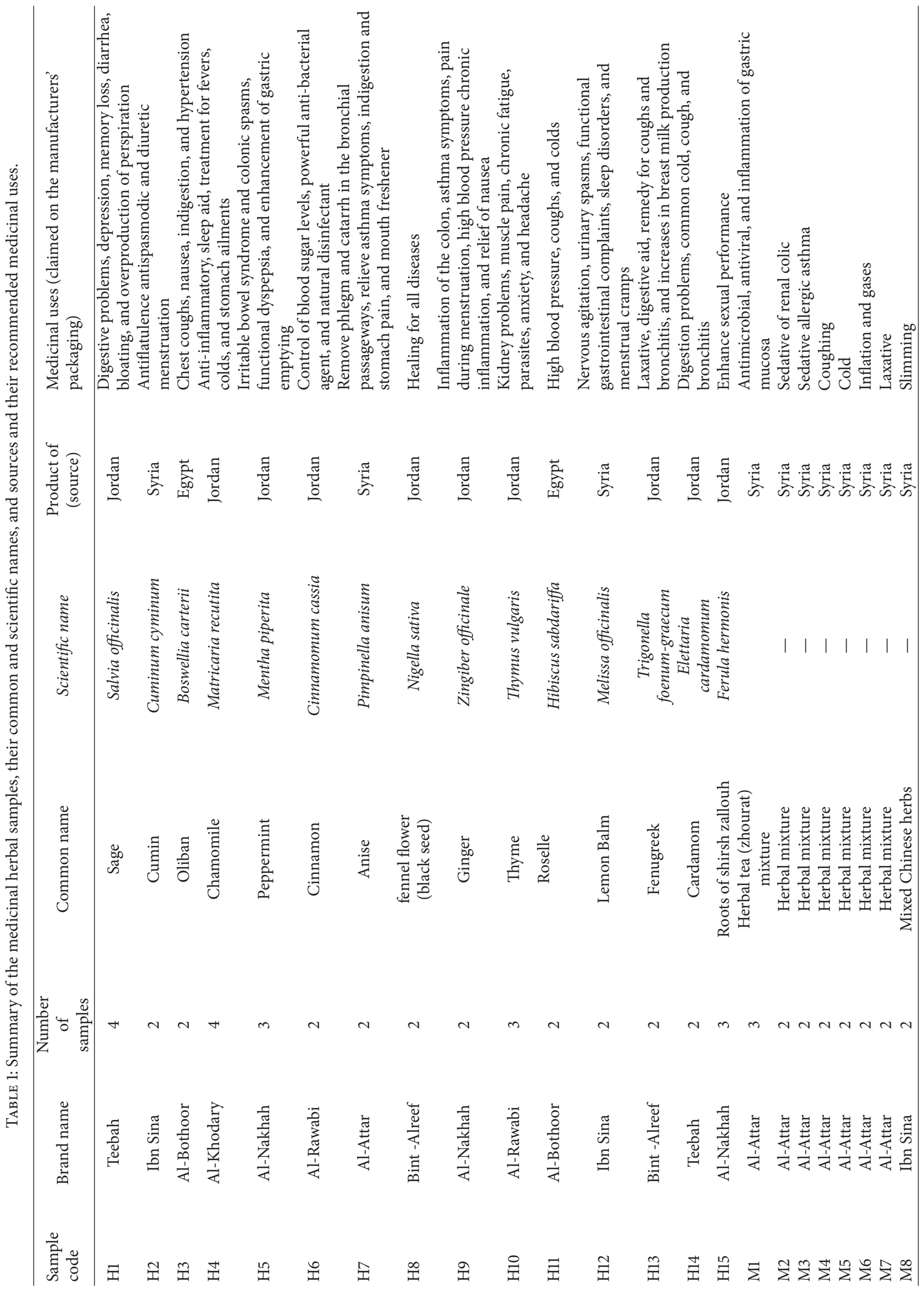



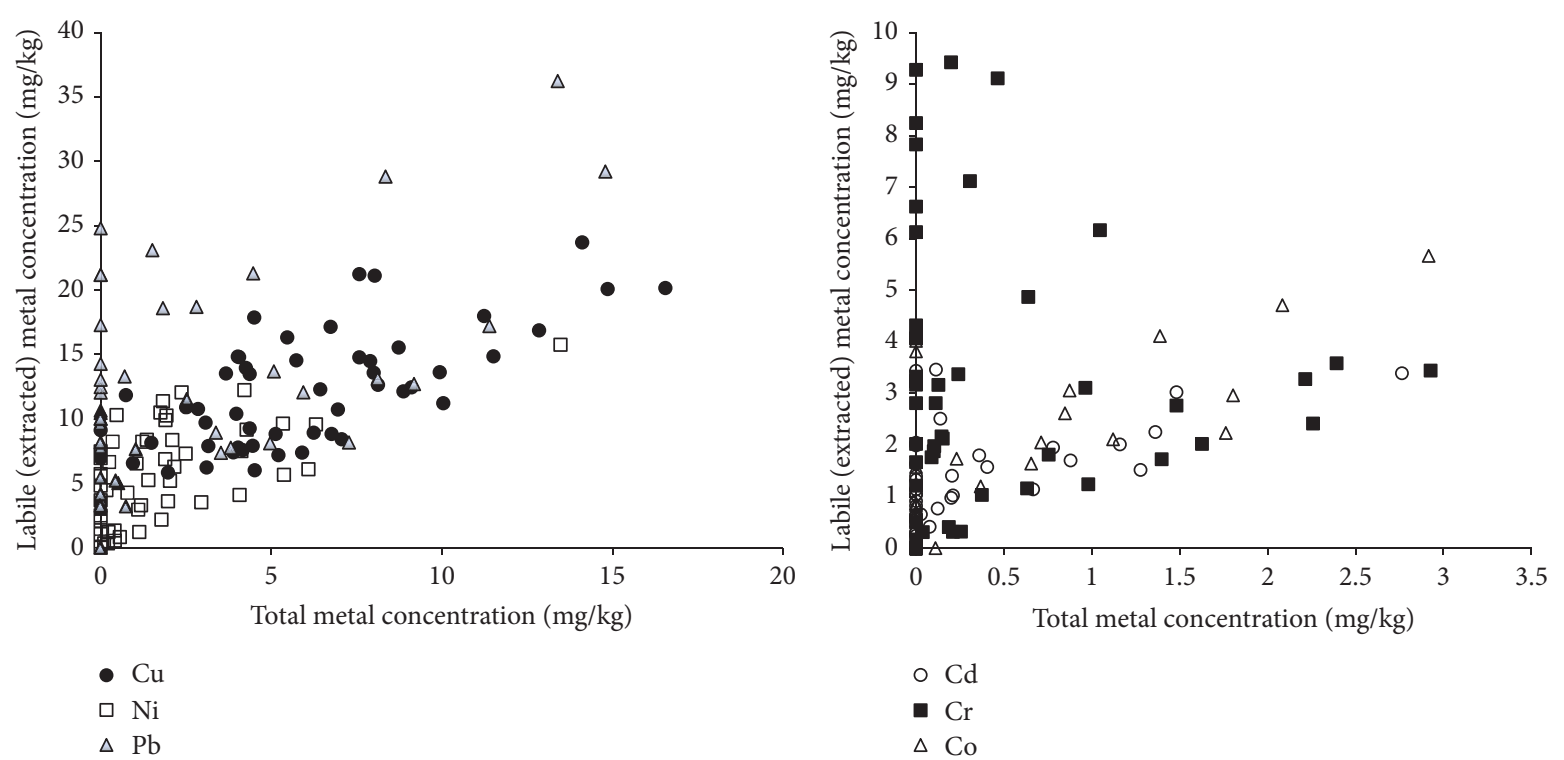

Figure 1: Relationship between $\mathrm{Cu}, \mathrm{Ni}, \mathrm{Pb}, \mathrm{Cd}, \mathrm{Cr}$, and $\mathrm{Co}$ content of the dried herbal samples and the extracted metal contents of the labile fractions in the infusions.

TABLE 2: Concentrations of selected elements in the NIST1570a certified reference material.

\begin{tabular}{lccc}
\hline Metal & $\begin{array}{c}\text { Certified value } \\
\mathrm{mg} / \mathrm{kg}\end{array}$ & $\begin{array}{c}\text { Measured value } \\
\mathrm{mg} / \mathrm{kg}\end{array}$ & Recovery \% \\
\hline $\mathrm{Mn}$ & 75.9 & 72 & 94.9 \\
$\mathrm{Zn}$ & 82 & 84 & 102.4 \\
$\mathrm{Ni}$ & 2.14 & 2.0 & 93.5 \\
$\mathrm{Co}$ & 0.39 & 0.36 & 92.3 \\
$\mathrm{Cu}$ & 12.2 & 11.3 & 92.6 \\
$\mathrm{Cd}$ & 2.89 & 2.59 & 89.6 \\
\hline
\end{tabular}

Iron and chromium had no significant correlations $(R$-square less than 0.004), while Mn has a strong correlation ( $R$-square 0.90 ). The metals $\mathrm{Zn}, \mathrm{Co}$, and $\mathrm{Cu}$ had good correlations with $R$-square values of $0.67,0.64$, and 0.5 respectively. Weak correlations were observed for $\mathrm{Ni}, \mathrm{Pb}$, and $\mathrm{Cd}$ with $R$-square values near 0.34 .

The extraction efficiency of metals from the herbal raw material to the water infusion was found to be influenced by the kind of herbal species, while Fe extraction efficiency was below $10 \%$ in most cases, it reaches more than $25 \%$ for ginger, cumin, and fennel flower. The extraction efficiencies for $\mathrm{Zn}$, $\mathrm{Cd}$, and $\mathrm{Pb}$ were high for roselle and exceed $60 \%$. Thyme infusion was found to contain $50 \%$ of the initial chromium amount.

\section{Discussion}

The average iron content of the medicinal herbs was in the range of $6.2 \mathrm{mg} / \mathrm{kg}$ to $1477 \mathrm{mg} / \mathrm{kg}$ with the lowest value in cumin and highest value in peppermint. Samples of chamomile, roots of shirsh zallouh, thyme, and sage had high iron concentrations of $824 \mathrm{mg} / \mathrm{kg}, 686 \mathrm{mg} / \mathrm{kg}, 556 \mathrm{mg} / \mathrm{kg}$, and $547 \mathrm{mg} / \mathrm{kg}$, respectively. The mean iron content of all the analyzed samples was $440 \mathrm{mg} / \mathrm{kg}$. In another related work, chamomile and sage had comparable iron contents of $502.7 \mathrm{mg} / \mathrm{kg}$ and $297.4 \mathrm{mg} / \mathrm{kg}$, respectively [17]. Similarly, iron concentration range $(83.5-405.43 \mathrm{mg} / \mathrm{kg}$ ) was reported for six herbal teas in another work [18]. Values between $104 \mathrm{mg} / \mathrm{kg}$ (white pepper) and $3125 \mathrm{mg} / \mathrm{kg}$ (chamomile) had also been reported [19]. However, high iron content $(3456 \mathrm{mg} / \mathrm{kg})$ was reported in nettle samples [16].

Manganese mean concentration was $162 \mathrm{mg} / \mathrm{kg}$ with a range of $1.8 \mathrm{mg} / \mathrm{kg}$ (oliban) to $715 \mathrm{mg} / \mathrm{kg}$ (roselle). In addition to roselle; the thyme, cinnamon, ginger, and chamomile samples were found to contain significant amounts of manganese as $324 \mathrm{mg} / \mathrm{kg}, 251 \mathrm{mg} / \mathrm{kg}, 250 \mathrm{mg} / \mathrm{kg}$, and $185 \mathrm{mg} / \mathrm{kg}$, respectively. Similar concentration range of manganese $(<6 \mathrm{mg} / \mathrm{kg}$ to $450.7 \mathrm{mg} / \mathrm{kg}$ ) was reported for some medicinal plants [20]. However, low manganese content with a range of $1.67 \mathrm{mg} / \mathrm{kg}$ to $138.1 \mathrm{mg} / \mathrm{kg}$ was reported for ten herbal samples [21]. Indeed, a wide concentration range of $25 \mathrm{mg} / \mathrm{kg}$ to $2722 \mathrm{mg} / \mathrm{kg}$ was reported for manganese in various plants (herbs, spices, and medicinal plants) [19].

Zinc and cooper were high in roselle $(141 \mathrm{mg} / \mathrm{kg})$ and peppermint $(23.7 \mathrm{mg} / \mathrm{kg})$, respectively. The mean zinc and copper concentrations in all of the analyzed herbal samples were $45.8 \mathrm{mg} / \mathrm{kg}$ and $12.0 \mathrm{mg} / \mathrm{kg}$, respectively. Zinc concentrations varied from $4.6 \mathrm{mg} / \mathrm{kg}$ to $141 \mathrm{mg} / \mathrm{kg}$ and copper concentrations ranged from $3.37 \mathrm{mg} / \mathrm{kg}$ to $23.7 \mathrm{mg} / \mathrm{kg}$. In a related work, similar concentrations ranges of zinc and copper were reported as $3.75-88 \mathrm{mg} / \mathrm{kg}$ and $3.32-30.2 \mathrm{mg} / \mathrm{kg}$, respectively [16]. In a recent work [22], copper in powdered herbal medicine was quantified at low concentration range of $0.89 \mathrm{mg} / \mathrm{kg}$ to $3.15 \mathrm{mg} / \mathrm{kg}$ while zinc had a concentration range of $8.5-38.9 \mathrm{mg} / \mathrm{kg}$. It has also been reported that zinc content of seven herbal plants ranged from $15.4 \mathrm{mg} / \mathrm{kg}$ to $73.7 \mathrm{mg} / \mathrm{kg}$ and that of copper ranged from $5 \mathrm{mg} / \mathrm{kg}$ to 
TABLE 3: The average contents of heavy metals $(\mathrm{mg} / \mathrm{kg})$ in the tested raw medicinal herbal samples.

\begin{tabular}{|c|c|c|c|c|c|c|c|c|c|}
\hline Sample code & $\mathrm{Zn}$ & $\mathrm{Fe}$ & $\mathrm{Cu}$ & Co & $\mathrm{Cr}$ & $\mathrm{Mn}$ & $\mathrm{Ni}$ & $\mathrm{Cd}$ & $\mathrm{Pb}$ \\
\hline H1 & $54.2 \pm 8.6$ & $574 \pm 260$ & $8.6 \pm 3.4$ & $1.8 \pm 1.3$ & $2.1 \pm 0.9$ & $99 \pm 136$ & $5.9 \pm 3.7$ & $0.7 \pm 0.4$ & $9.2 \pm 7.7$ \\
\hline $\mathrm{H} 2$ & $51.8 \pm 11.4$ & $6.60 \pm 0.55$ & $13.5 \pm 1.8$ & $<0.03$ & $2.7 \pm 0.7$ & $28.7 \pm 9.1$ & $6.34 \pm 2.7$ & $0.2 \pm 0.04$ & $5.5 \pm 3.2$ \\
\hline $\mathrm{H} 3$ & $4.9 \pm 0.4$ & $49.5 \pm 3.9$ & $7.9 \pm 0.7$ & $<0.03$ & $3.7 \pm 0.6$ & $2.1 \pm 0.3$ & $1.9 \pm 0.9$ & $0.5 \pm 0.1$ & $17.7 \pm 4.8$ \\
\hline $\mathrm{H} 4$ & $49.8 \pm 3.3$ & $824 \pm 344$ & $12.6 \pm 1.3$ & $<0.03$ & $1.52 \pm 1.3$ & $185 \pm 209$ & $3.05 \pm 2.8$ & $0.17 \pm 0.34$ & $8.01 \pm 5.4$ \\
\hline H5 & $39.6 \pm 12$ & $1121 \pm 308$ & $16.9 \pm 5.9$ & $1.02 \pm 1.1$ & $3.10 \pm 0.6$ & $148 \pm 41$ & $4.45 \pm 3.7$ & $0.63 \pm 0.58$ & $16.2 \pm 3.1$ \\
\hline H6 & $24.7 \pm 1.9$ & $171 \pm 14.7$ & $7.12 \pm 5.3$ & $0.04 \pm 0.04$ & $<0.04$ & $251 \pm 92$ & $0.67 \pm 0.93$ & $0.25 \pm 0.36$ & $7.90 \pm 0.36$ \\
\hline $\mathrm{H} 7$ & $72.3 \pm 21.1$ & $86.2 \pm 111$ & $13.9 \pm 4.5$ & $1.65 \pm 0.56$ & $2.1 \pm 2.7$ & $57.7 \pm 0.2$ & $3.98 \pm 4.9$ & $0.38 \pm 0.15$ & $5.33 \pm 3.3$ \\
\hline $\mathrm{H} 8$ & $59.4 \pm 2.2$ & $7.4 \pm 0.6$ & $16.3 \pm 2.2$ & $0.77 \pm 0.13$ & $1.8 \pm 0.2$ & $20.5 \pm 6.2$ & $3.91 \pm 2.4$ & $<0.01$ & $<0.04$ \\
\hline $\mathrm{H} 9$ & $26.3 \pm 4.9$ & $136 \pm 89$ & $6.70 \pm 1$ & $<0.03$ & $3.2 \pm 4.1$ & $250 \pm 112$ & $2.4 \pm 1.6$ & $0.62 \pm 0.06$ & $11.0 \pm 1.4$ \\
\hline H10 & $46.5 \pm 11.8$ & $556 \pm 139$ & $17.3 \pm 2.4$ & $0.29 \pm 0.5$ & $0.71 \pm 0.09$ & $324 \pm 252$ & $2.47 \pm 1.7$ & $0.92 \pm 0.5$ & $19.3 \pm 10.6$ \\
\hline H11 & $135 \pm 8.5$ & $328 \pm 30.5$ & $14.7 \pm 3.1$ & $5.19 \pm 0.67$ & $5.52 \pm 0.9$ & $660 \pm 77$ & $12.7 \pm 4.3$ & $1.01 \pm 0.9$ & $17.4 \pm 10.4$ \\
\hline H12 & $38.9 \pm 15.1$ & $437 \pm 33.6$ & $9.79 \pm 1.3$ & $0.60 \pm 0.8$ & $1.88 \pm 2.2$ & $69.3 \pm 2.7$ & $6.01 \pm 3.3$ & $0.69 \pm 0.9$ & $6.56 \pm 9.2$ \\
\hline H13 & $36.4 \pm 5.5$ & $24.8 \pm 4.2$ & $9.13 \pm 1.7$ & $<0.03$ & $<0.04$ & $26.5 \pm 15.1$ & $0.53 \pm 0.8$ & $<0.01$ & $<0.01$ \\
\hline H14 & $36.7 \pm 6.1$ & $311 \pm 16.1$ & $17.5 \pm 3.7$ & $0.07 \pm 0.4$ & $0.21 \pm 0.29$ & $382 \pm 14$ & $4.27 \pm 1.39$ & $0.40 \pm 0.16$ & $8.26 \pm 4.61$ \\
\hline H15 & $35.3 \pm 13.2$ & $686 \pm 108$ & $7.77 \pm 1.17$ & $<0.03$ & $6.74 \pm 2.47$ & $39.7 \pm 20$ & $8.40 \pm 1.8$ & $0.66 \pm 0.26$ & $8.14 \pm 4.33$ \\
\hline M1 & $45.6 \pm 5.7$ & $519 \pm 321$ & $14.5 \pm 6.2$ & $0.18 \pm 0.3$ & $3.75 \pm 3.8$ & $353 \pm 65$ & $7.25 \pm 6.17$ & $0.44 \pm 0.5$ & $5.74 \pm 9.9$ \\
\hline M2 & $52.9 \pm 7.6$ & $693 \pm 64$ & $6.89 \pm 0.9$ & $<0.03$ & $2.40 \pm 0.6$ & $69.7 \pm 17.6$ & $8.38 \pm 2.1$ & $<0.01$ & $18.20 \pm 6.9$ \\
\hline M3 & $56.6 \pm 18.4$ & $800 \pm 72$ & $15.8 \pm 3.1$ & $3.92 \pm 0.14$ & $2.00 \pm 0.17$ & $85.2 \pm 10.8$ & $11.2 \pm 1.3$ & $1.27 \pm 0.63$ & $18.6 \pm 8.2$ \\
\hline M4 & $40.9 \pm 7.0$ & $570 \pm 114$ & $10.5 \pm 2.3$ & $3.59 \pm 0.74$ & $2.99 \pm 0.26$ & $76.7 \pm 10$ & $10.9 \pm 0.62$ & $<0.01$ & $6.1 \pm 4.0$ \\
\hline M5 & $41.0 \pm 4.5$ & $282 \pm 63$ & $8.5 \pm 1.1$ & $1.87 \pm 0.33$ & $8.67 \pm 0.61$ & $182 \pm 31$ & $6.2 \pm 1.5$ & $0.38 \pm 0.1$ & $9.2 \pm 5.3$ \\
\hline M6 & $37.5 \pm 8.4$ & $13.1 \pm 5.3$ & $17.9 \pm 4.7$ & $0.78 \pm 1.1$ & $8.27 \pm 1.6$ & $56.4 \pm 9.6$ & $7.7 \pm 1.0$ & $0.15 \pm 0.05$ & $18.6 \pm 26.0$ \\
\hline M7 & $26.1 \pm 3.5$ & $62.4 \pm 18.3$ & $7.3 \pm 1.1$ & $<0.03$ & $2.94 \pm 0.24$ & $24.9 \pm 7.4$ & $4.6 \pm 2.3$ & $0.76 \pm 0.34$ & $4.24 \pm 1.3$ \\
\hline M8 & $37.3 \pm 5.9$ & $783 \pm 59$ & $12.3 \pm 3.6$ & $0.34 \pm 0.48$ & $1.48 \pm 0.34$ & $276 \pm 59$ & $4.2 \pm 0.8$ & $1.25 \pm 0.36$ & $28.7 \pm 10.5$ \\
\hline \multicolumn{10}{|c|}{ Statistical values of all 54 samples } \\
\hline Highest & 141 & 1477 & 23.7 & 5.67 & 9.43 & 715 & 15.7 & 1.25 & 28.7 \\
\hline Lowest & 4.63 & 6.23 & 3.37 & nd & nd & 1.82 & 0.53 & nd & nd \\
\hline Mean & 45.8 & 440 & 12.0 & 0.91 & 2.90 & 162 & 5.44 & 0.5 & 10.4 \\
\hline Median & 43.7 & 409 & 11.5 & 0 & 2.29 & 79.9 & 5.40 & 0.4 & 9.25 \\
\hline St. dev. & 23.1 & 357 & 4.62 & 1.44 & 2.60 & 172 & 3.82 & 0.45 & 8.44 \\
\hline
\end{tabular}

TABLE 4: Average contents of heavy metals $(\mathrm{mg} / \mathrm{kg})$ in the raw samples and water infusions of the medicinal herbs.

\begin{tabular}{|c|c|c|c|c|c|c|c|c|c|}
\hline Element & $\mathrm{Zn}$ & $\mathrm{Fe}$ & $\mathrm{Cu}$ & Co & $\mathrm{Cr}$ & $\mathrm{Mn}$ & $\mathrm{Ni}$ & $\mathrm{Cd}$ & $\mathrm{Pb}$ \\
\hline Dried herbs (mg/kg) & $45.8 \pm 5.1$ & $440 \pm 77$ & $12 \pm 1.0$ & $0.91 \pm 0.3$ & $2.9 \pm 0.6$ & $162 \pm 38$ & $5.4 \pm 0.8$ & $0.5 \pm 0.1$ & $10.4 \pm 1.8$ \\
\hline Infusions (mg/kg) & $16.5 \pm 3.7$ & $15.6 \pm 4.3$ & $5.8 \pm 0.8$ & $0.26 \pm 0.1$ & $0.4 \pm 0.1$ & $86 \pm 9$ & $1.7 \pm 0.5$ & $0.07 \pm 0.1$ & $2.1 \pm 0.8$ \\
\hline Extraction efficiency (\%) & $36 \pm 4$ & $3.5 \pm 4$ & $48 \pm 5$ & $29 \pm 5$ & $15 \pm 7$ & $53 \pm 6$ & $31 \pm 7$ & $14 \pm 6$ & $20 \pm 5$ \\
\hline
\end{tabular}

$32.7 \mathrm{mg} / \mathrm{kg}$ [23].The previous mentioned results were in good agreement with the reported values for both zinc and copper concentrations obtained in this work.

Lead and cadmium are toxic elements for human; they perform no beneficial biological roles and can be very dangerous even at low concentrations. The highest mean concentration of lead in individual herbs was detected in thyme $(19.3 \mathrm{mg} / \mathrm{kg})$ followed by oliban $(17.7 \mathrm{mg} / \mathrm{kg})$, roselle $(17.4 \mathrm{mg} / \mathrm{kg})$, and peppermint $(16.2 \mathrm{mg} / \mathrm{kg})$. Among the mixtures of herbs, the Chinese herbal mixture for slimming was found to contain a high mean concentration of lead $(28.7 \mathrm{mg} / \mathrm{kg})$. The lowest mean concentration of lead was observed in fennel flower (black seed) and fenugreek where it was below the detection limit $(0.06 \mathrm{mg} / \mathrm{kg})$. The mean concentration of lead in all of the analyzed samples was
$10.4 \mathrm{mg} / \mathrm{kg}$. Comparable result for the lead concentration range has recently been reported as from below detection limit to $33.8 \mathrm{mg} / \mathrm{kg}$ [22]. In related work, thyme was shown to contain $6.45-8.63 \mathrm{mg} / \mathrm{kg}$ of lead [12]. On the other hand, low to moderate concentration ranges of lead $0.35 \mathrm{mg} / \mathrm{kg}-0.82 \mathrm{mg} / \mathrm{kg}$ [24], $0.02 \mathrm{mg} / \mathrm{kg}-3.01 \mathrm{mg} / \mathrm{kg}$ [16], $0.26 \mathrm{mg} / \mathrm{kg}-4.8 \mathrm{mg} / \mathrm{kg}$ [17], $0.27 \mathrm{mg} / \mathrm{kg}-11 \mathrm{mg} / \mathrm{kg}$ [25], and $0.04 \mathrm{mg} / \mathrm{kg}-8.15 \mathrm{mg} / \mathrm{kg}$ [26] were reported in various medicinal plants.

The content of cadmium in the analyzed herbs varied between $<0.04 \mathrm{mg} / \mathrm{kg}$ and $1.27 \mathrm{mg} / \mathrm{kg}$ with an average value of $0.5 \mathrm{mg} / \mathrm{kg}$. The highest cadmium content was found in allergic asthma mixture ( $\operatorname{mix} 3$ ) as $1.27 \mathrm{mg} / \mathrm{kg}$ and Chinese herbal mixture (mix 8 ) as $1.25 \mathrm{mg} / \mathrm{kg}$. In the individual herbs, cadmium was detected at high concentrations in roselle 

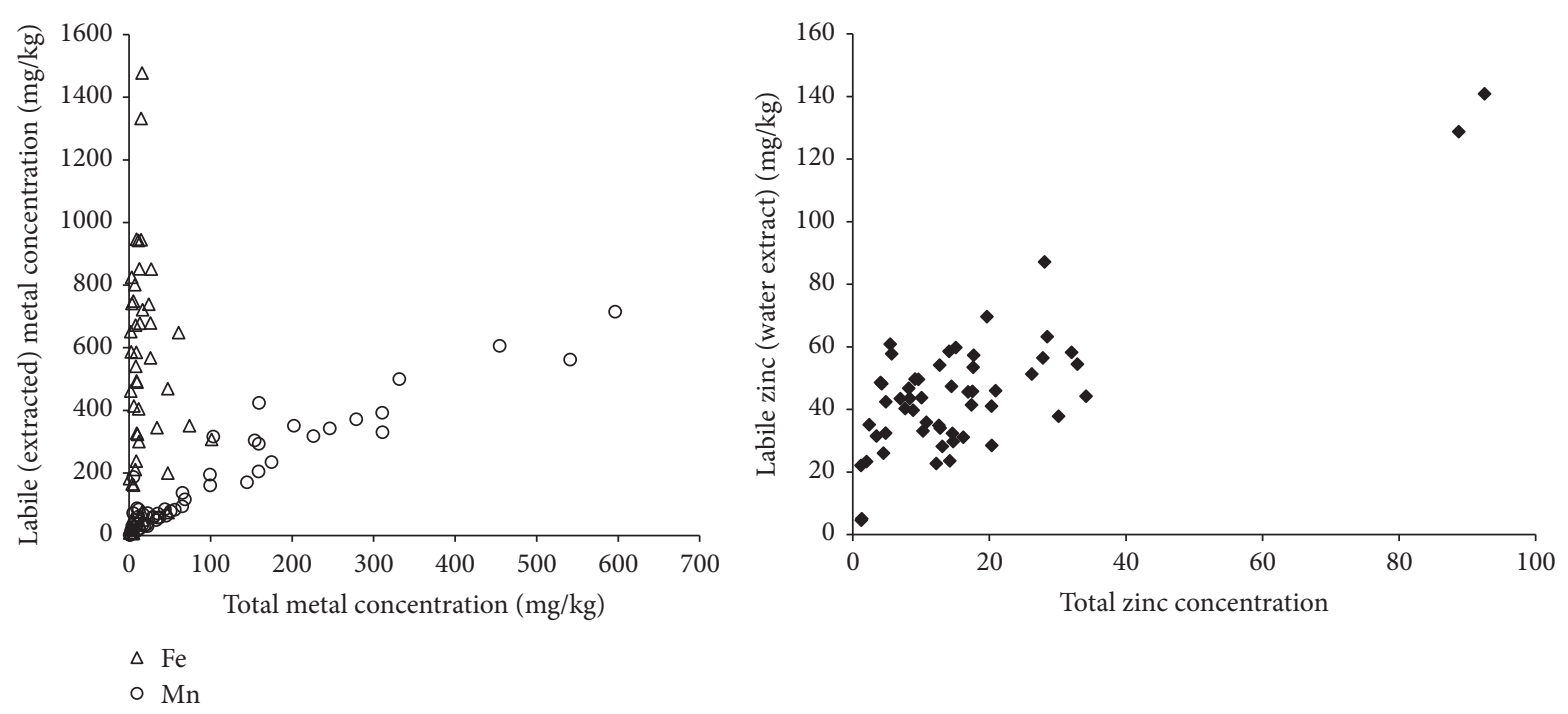

Figure 2: Relationship between Fe, Mn, and $\mathrm{Zn}$ contents of the dried herbal samples and the extracted metal contents of the labile fractions in the infusions.

$(1.01 \mathrm{mg} / \mathrm{kg})$, thyme $(0.92 \mathrm{mg} / \mathrm{kg})$, lemon balm $(0.69 \mathrm{mg} / \mathrm{kg})$, and sage $(0.65 \mathrm{mg} / \mathrm{kg})$. Comparing the results obtained in this research with results found in the literature, the cadmium concentration range is similar to that reported by Onwordil et al. for various types of herbal medicines $(0.48-3.08 \mathrm{mg} / \mathrm{kg})$ [22], the results of Subramanian et al. $(0.68-2.75 \mathrm{mg} / \mathrm{kg})$ [27], and that of Harris et al. (0.04-4.35 mg/kg) [26]. However, lower mean concentration and concentration ranges than the results of this work were reported. For instance, cadmium concentrations were found in the ranges of below the detection limit to a maximum of $0.44 \mathrm{mg} / \mathrm{kg}$ [17], $0.015 \mathrm{mg} / \mathrm{kg}$ to $0.268 \mathrm{mg} / \mathrm{kg}$ [12], $0.007 \mathrm{mg} / \mathrm{kg}$ to $0.27 \mathrm{mg} / \mathrm{kg}$ [25], and from below the detection limit to $0.195 \mathrm{mg} / \mathrm{kg}$ [28].

The concentration ranges of nickel and chromium are similar; they were measured as from $0.53 \mathrm{mg} / \mathrm{kg}$ to $15.7 \mathrm{mg} / \mathrm{kg}$ and from $<0.03$ to 9.43 , respectively. The mean nickel and chromium concentrations in all of the analyzed herbal samples were $5.44 \mathrm{mg} / \mathrm{kg}$ and $2.9 \mathrm{mg} / \mathrm{kg}$, respectively. In related work, a concentration range of $0.72 \mathrm{mg} / \mathrm{kg}-13.1 \mathrm{mg} / \mathrm{kg}$ with an average of $3.62 \mathrm{mg} / \mathrm{kg}$ and a concentration range 0.44 to 8.71 with an average of 2.5 have been reported for nickel and chromium, respectively [16]. Similarly, nickel and chromium concentration ranges were reported as $0.55 \mathrm{mg} / \mathrm{kg}$ to $7.31 \mathrm{mg} / \mathrm{kg}$ and $0.222 \mathrm{mg} / \mathrm{kg}-2.4 \mathrm{mg} / \mathrm{kg}$, respectively [29]. The results obtained in this work also agree well with the reported data $0.90-5.4 \mathrm{mg} / \mathrm{kg}$ and 0.34 to $1.22 \mathrm{mg} / \mathrm{kg}$ for the concentration ranges of $\mathrm{Ni}$ and $\mathrm{Cr}$, respectively [17].

Cobalt is the least detected element in the analyzed herbs; it was quantified in $54 \%$ of the samples in the range of $<0.03 \mathrm{mg} / \mathrm{kg}$ to $5.67 \mathrm{mg} / \mathrm{kg}$ with mean value of $0.91 \mathrm{mg} / \mathrm{kg}$. High mean concentrations of cobalt were detected in roselle $(5.19 \mathrm{mg} / \mathrm{kg})$, sage $(1.83 \mathrm{mg} / \mathrm{kg})$, anise $(1.6 \mathrm{mg} / \mathrm{kg})$, and peppermint $(1.02 \mathrm{mg} / \mathrm{kg})$. In the herbal mixture, high cobalt concentrations were found in allergic asthma mixture (mix 3) $(3.92 \mathrm{mg} / \mathrm{kg})$ and coughing mixture (mix 3) $(3.59 \mathrm{mg} / \mathrm{kg})$. Comparable results for the cobalt concentration ranges in herbal medicines have been reported as $0.05-2.35 \mathrm{mg} / \mathrm{kg}$ [16],
$0.08-3.23 \mathrm{mg} / \mathrm{kg}$ [29], 0.14-0.48 $\mathrm{mg} / \mathrm{kg}$ [17], and from below detection limit to $0.87 \mathrm{mg} / \mathrm{kg}$ [28].

The extraction efficiencies of various metals from raw material to the water infusions were found to be variable; this was also observed by other related studies. For instance, Queralt et al. [30] showed that the average mass percentage of transported elements to the infusion solution (water at $70^{\circ} \mathrm{C}$ ) are as follows (Mn: $32 \%$, Cu: $30 \%, \mathrm{Zn}: 24 \%, \mathrm{~Pb}: 22 \%$, and Fe: $1 \%$ ); these results are comparable with the results of the present study. In another work, the following sequence of extraction efficiencies was observed (Cd: $53.1 \%, \mathrm{~Pb}: 47.5 \%$, $\mathrm{Zn:} 39.02 \%, \mathrm{Mn}: 19.98 \%, \mathrm{Cu}: 14.4 \%$, and $\mathrm{Fe}: 10.09 \%$ ) [26]; the results for $\mathrm{Cd}, \mathrm{Pb}$, and $\mathrm{Mn}$ were in conflict with the results obtained in the present study. However, in agreement with results of the present study, a recent study showed that the extraction efficiencies for $\mathrm{Pb}$ and $\mathrm{Cd}$ from raw material of herbs to the infusion solutions were $4.3 \%$ and $4.1 \%$, respectively [31]. In another related work, the extraction efficiencies of various metals from ten herbs were reported as $\mathrm{Zn:} 35 \%$, $\mathrm{Cu}: 33 \%, \mathrm{Mn}: 24 \%$, and Fe: $6 \%$ [32]. In a recent work, the leaching of $\mathrm{Ni}$ and $\mathrm{Mn}$ to the infusion solutions was reported as the highest, while Fe was the least [33]; the mentioned results were in good agreement with the present study results.

Because of the toxic properties of lead and cadmium, it is important to evaluate the safety of the herbal preparation. In this work the two toxic elements lead and cadmium were quantified in the raw materials of herbal remedies with average values close to or slightly above their permissible limits of $10 \mathrm{mg} / \mathrm{kg}$ and $0.3 \mathrm{mg} / \mathrm{kg}$, respectively. It was found that $40 \%$ of the analyzed samples contain more than $10 \mathrm{mg} / \mathrm{kg}$ of lead and $60 \%$ of the analyzed samples contain more than $0.3 \mathrm{mg} / \mathrm{kg}$ of cadmium, while $30 \%$ of the samples contain the two elements above their permissible limits. Indeed, the determination of total concentration of the toxic elements in the herbal raw materials gives indication of the toxicity of the herbal preparation, but this step is not sufficient in 
assessing the safety of these products because the consumers take these remedies as recommended by the producers as their infusion in hot water. In fact, all infusions were found to contain fewer amounts of metals than the raw materials, and so it is important to evaluate the infusions for their safety. By assuming the consumption of $200 \mathrm{ml}$ infusion prepared from 2-scahets $(2 \mathrm{~g})$ two times a day, as recommended by the manufacturer, and by using the mean value of the \% extraction efficiency for $\mathrm{Pb}$ and $\mathrm{Cd}$, the estimated daily intake was calculated as $8.32 \mu \mathrm{g} /$ day and $0.28 \mu \mathrm{g} /$ day for $\mathrm{Pb}$ and $\mathrm{Cd}$, respectively. These values were far below the tolerable daily intake of $\mathrm{Pb}(0.3 \mathrm{mg} /$ day $)$ and $\mathrm{Cd}$ (1.5 ug/day). The amounts of essential trace elements were very low in the infusions, and the estimated daily intake was calculated as $0.06 \mathrm{mg} / \mathrm{day}$, $0.07 \mathrm{mg} / \mathrm{day}, 3.36 \mu \mathrm{g} /$ day, and $23 \mu \mathrm{g} /$ day for $\mathrm{Fe}, \mathrm{Zn}, \mathrm{Cr}$, and $\mathrm{Cu}$, respectively. It is clearly calculated that there is no health risk associated with the consumption of these herbal products with respect to their metal contents. However, the content of $\mathrm{Pb}$ and $\mathrm{Cd}$ must be monitored frequently to avoid the accumulation of these toxic elements.

\section{Conclusions}

Quantification of nine metal elements (Fe, Mn, $\mathrm{Zn}, \mathrm{Cu}, \mathrm{Cr}$, $\mathrm{Co}, \mathrm{Ni}, \mathrm{Pb}$, and $\mathrm{Cd}$ ) in the raw materials and water infusions of selected herbal remedies and comparison with the values in the literature revealed that the heavy metal contents of these commercially available products vary and are affected by the plant species. In the raw materials, Fe had the highest mean content $(440 \mathrm{mg} / \mathrm{kg})$ and $\mathrm{Cd}$ had the lowest mean content $(0.5 \mathrm{mg} / \mathrm{kg})$. Mn and $\mathrm{Cu}$ demonstrated relatively high extraction efficiencies to the infusions while Fe had the lowest extraction efficiency. Some raw herbal materials had lead and cadmium contents above the permissible limits. However, the water infusions of these medicinal preparations contain lower levels of lead and cadmium and consumption of the tested beverages poses no risk to human health.

\section{Conflicts of Interest}

The author declares no conflicts of interest.

\section{Acknowledgments}

The author acknowledges Al-Hussein bin Talal University for the sabbatical leave.

\section{References}

[1] R. Ciriminna, D. Carnaroglio, R. Delisi, S. Arvati, A. Tamburino, and M. Pagliaro, "Industrial Feasibility of Natural Products Extraction with Microwave Technology," ChemistrySelect, vol. 1, no. 3, pp. 549-555, 2016.

[2] J. E. Gall, R. S. Boyd, and N. Rajakaruna, "Transfer of heavy metals through terrestrial food webs: a review," Environmental Modeling \& Assessment, vol. 187, no. 4, 2015.

[3] M. Mania, M. Wojciechowska-Mazurek, K. Starska et al., "Toxic Elements in Commercial Infant Food, Estimated Dietary
Intake, and Risk Assessment in Poland," Polish Journal of Environmental Studies, vol. 24, no. 6, pp. 2525-2536, 2015.

[4] S. Clemens and J. F. Ma, "Toxic heavy metal and metalloid accumulation in crop plants and foods," Annual Review of Plant Biology, vol. 67, no. 1, pp. 489-512, 2016.

[5] L. B. Seeff, H. L. Bonkovsky, V. J. Navarro, and G. Wang, "Herbal products and the liver: A review of adverse effects and mechanisms," Gastroenterology, vol. 148, no. 3, pp. 517-532.e3, 2015.

[6] P. D. Blanc, L. Trupin, G. Earnest, P. P. Katz, E. H. Yelin, and M. D. Eisner, "Alternative therapies among adults with a reported diagnosis of asthma or rhinosinusitis: data from a populationbased survey," CHEST, vol. 120, no. 5, pp. 1461-1467, 2001.

[7] M. M. Storelli, "Evaluation of toxic metal ( $\mathrm{Hg}, \mathrm{Cd}, \mathrm{Pb})$, polychlorinated biphenyl (PCBs), and pesticide (DDTs) levels in aromatic herbs collected in selected areas of Southern Italy," Environmental Science and Pollution Research, vol. 21, no. 2, pp. 946-953, 2014.

[8] C. Locatelli, D. Melucci, and M. Locatelli, "Toxic metals in herbal medicines. A review," Current Bioactive Compounds, vol. 10, no. 3, pp. 181-188, 2014.

[9] H. Sarma, S. Deka, H. Deka, and R. R. Saikia, "Accumulation of heavy metals in selected medicinal plants," Reviews of Environmental Contamination and Toxicology, vol. 214, pp. 6386, 2011.

[10] B. E. Birgisdottir, H. K. Knutsen, M. Haugen et al., "Essential and toxic element concentrations in blood and urine and their associations with diet: Results from a Norwegian population study including high-consumers of seafood and game," Science of the Total Environment, vol. 463-464, pp. 836-844, 2013.

[11] M. M. Rao, A. K. Meena, and Galib, "Detection of toxic heavy metals and pesticide residue in herbal plants which are commonly used in the herbal formulations," Environmental Modeling \& Assessment, vol. 181, no. 1-4, pp. 267-271, 2011.

[12] S. Arpadjan, G. Çelik, S. Taşkesen, and Ş. Güçer, "Arsenic, cadmium and lead in medicinal herbs and their fractionation," Food and Chemical Toxicology, vol. 46, no. 8, pp. 2871-2875, 2008.

[13] A. Okem, C. Southway, W. A. Stirk, R. A. Street, J. F. Finnie, and J. Van Staden, "Heavy metal contamination in South African medicinal plants: A cause for concern," South African Journal of Botany, vol. 93, pp. 125-130, 2014.

[14] M. Özcan, A. Ünver, T. Uçar, and D. Arslan, "Mineral content of some herbs and herbal teas by infusion and decoction," Food Chemistry, vol. 106, no. 3, pp. 1120-1127, 2008.

[15] I. Juranović Cindrić, M. Zeiner, E. Glamuzina, and G. Stingeder, "Elemental characterisation of the medical herbs Salvia officinalis L. and Teucrium montanum L. grown in Croatia," Microchemical Journal, vol. 107, pp. 185-189, 2013.

[16] Ş. Tokalioğlu, "Determination of trace elements in commonly consumed medicinal herbs by ICP-MS and multivariate analysis," Food Chemistry, vol. 134, no. 4, pp. 2504-2508, 2012.

[17] S. Başgel and S. B. Erdemoğlu, "Determination of mineral and trace elements in some medicinal herbs and their infusions consumed in Turkey," Science of the Total Environment, vol. 359, no. 1-3, pp. 82-89, 2006.

[18] I. Sembratowicz and E. Rusinek-Prystupa, "Effects of brewing time on the content of minerals in infusions of medicinal herbs," Polish Journal of Environmental Studies, vol. 23, no. 1, article 177, 2014.

[19] I. De La Calle, M. Costas, N. Cabaleiro, I. Lavilla, and C. Bendicho, "Fast method for multielemental analysis of plants 
and discrimination according to the anatomical part by total reflection X-ray fluorescence spectrometry," Food Chemistry, vol. 138, no. 1, pp. 234-241, 2013.

[20] D. Desideri, M. A. Meli, and C. Roselli, "Determination of essential and non-essential elements in some medicinal plants by polarised X-ray fluorescence spectrometer (EDPXRF)," Microchemical Journal, vol. 95, no. 2, pp. 174-180, 2010.

[21] A. K. Meena, P. Bansal, S. Kumar, M. M. Rao, and V. K. Garg, "Estimation of heavy metals in commonly used medicinal plants: a market basket survey," Environmental Modeling \& Assessment, vol. 170, no. 1, pp. 657-660, 2010.

[22] C. T. Onwordil, N. Agbo, and I. A. Ogunwande, "levels of potentially toxic metals in selected herbal medicines in Lagos, Nigeria," Journal of Natural Sciences Research, vol. 5, no. 2, article 148, 2015.

[23] M. G. Sheded, I. D. Pulford, and A. I. Hamed, "Presence of major and trace elements in seven medicinal plants growing in the South-Eastern Desert, Egypt," Journal of Arid Environments, vol. 66, no. 2, pp. 210-217, 2006.

[24] A. Filipiak-Szok, M. Kurzawa, and E. Szłyk, "Determination of toxic metals by ICP-MS in Asiatic and European medicinal plants and dietary supplements," Journal of Trace Elements in Medicine and Biology, vol. 30, pp. 54-58, 2015.

[25] M. C. V. Mamani, L. M. Aleixo, M. F. De Abreu, and S. Rath, "Simultaneous determination of cadmium and lead in medicinal plants by anodic stripping voltammetry," Journal of Pharmaceutical and Biomedical Analysis, vol. 37, no. 4, pp. 709713, 2005.

[26] E. S. J. Harris, S. Cao, B. A. Littlefield et al., "Heavy metal and pesticide content in commonly prescribed individual raw Chinese Herbal Medicines," Science of the Total Environment, vol. 409, no. 20, pp. 4297-4305, 2011.

[27] R. Subramanian, S. Gayathri, C. Rathnavel, and V. Raj, "Analysis of mineral and heavy metals in some medicinal plants collected from local market," Asian Pacific Journal of Tropical Biomedicine, vol. 2, no. 1, pp. S74-S78, 2012.

[28] A. A. Adepoju-Bello, O. A. Issa, O. O. Oguntibeju, G. A. Ayoola, and O. O. Adejumo, "Analysis of some selected toxic metals in registered herbal products manufactured in Nigeria," African Journal of Biotechnology, vol. 11, no. 26, article 6918, 2012.

[29] K. Bu, J. V. Cizdziel, and L. Reidy, "Analysis of herbal supplements for selected dietary minerals and trace elements by laser ablation- and solution-based ICPMS," Microchemical Journal, vol. 106, pp. 244-249, 2013.

[30] I. Queralt, M. Ovejero, M. L. Carvalho, A. F. Marques, and J. M. Llabrés, "Quantitative determination of essential and trace element content of medicinal plants and their infusions by XRF and ICF techniques," X-Ray Spectrometry, vol. 34, no. 3, pp. 213217, 2005.

[31] D.-G. Kim, S.-D. Lee, I.-S. Yu, K. Jung, and S.-K. Park, “Transfer rates of toxic metals during decoction preparation from hebal medicines and safety evaluation of the final decoction products," Food Science and Biotechnology, vol. 24, no. 2, pp. 757-763, 2015.

[32] R. N. Gallaher, K. Gallaher, A. J. Marshall, and A. C. Marshall, "Mineral analysis of ten types of commercially available tea," Journal of Food Composition and Analysis, vol. 19, pp. S53-S57, 2006.

[33] L. Polechońska, M. Dambiec, A. Klink, and A. Rudecki, "Concentrations and solubility of selected trace metals in leaf and bagged black teas commercialized in Poland," Journal of Food and Drug Analysis, vol. 23, no. 3, pp. 486-492, 2015. 

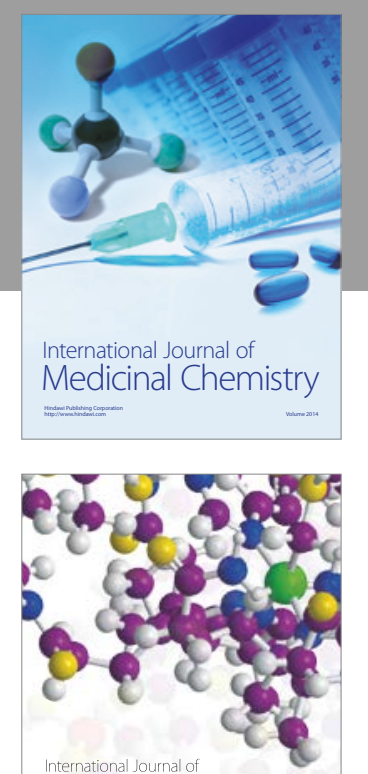

Carbohydrate Chemistry

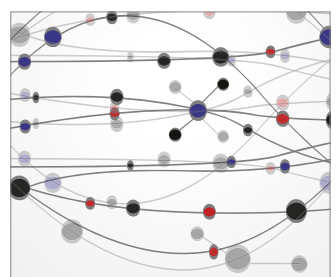

The Scientific World Journal
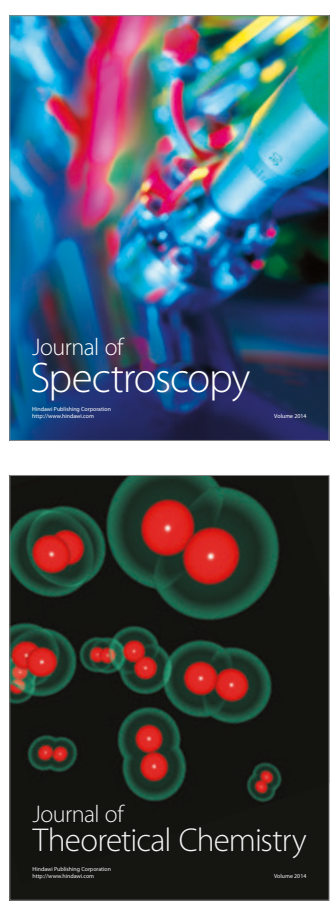
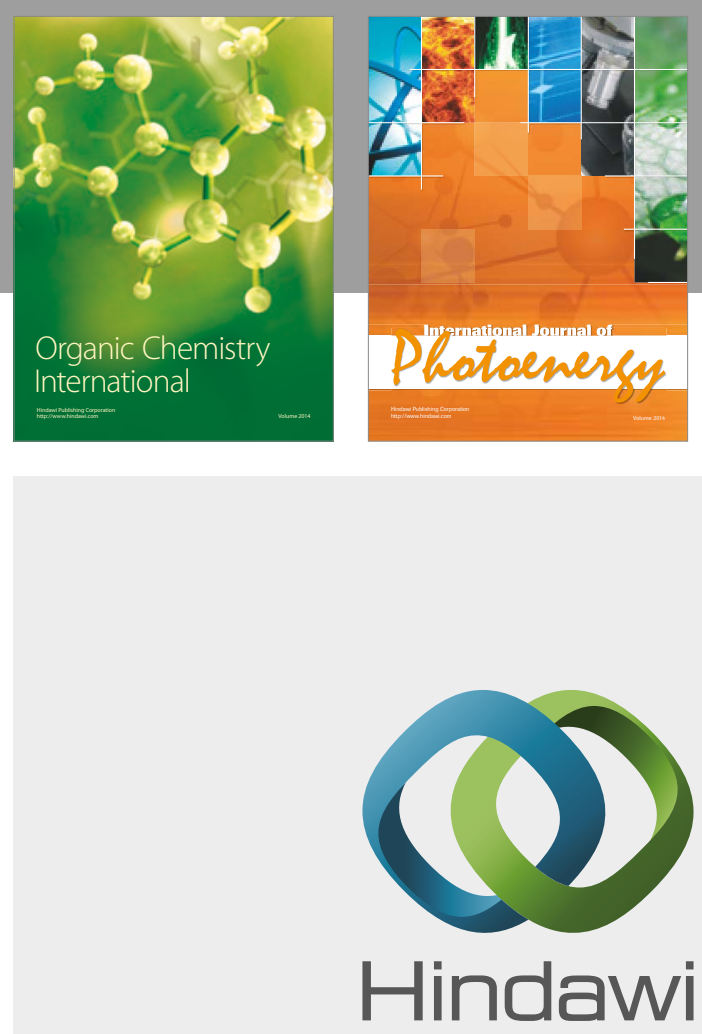

Submit your manuscripts at

https://www.hindawi.com

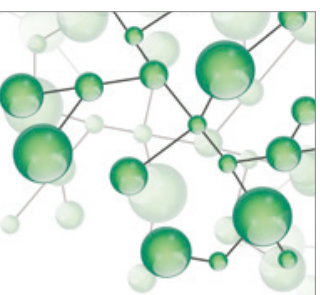

International Journal of

Inorganic Chemistry

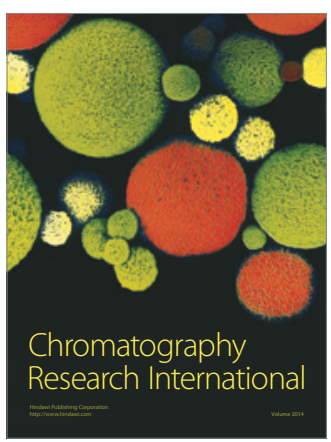

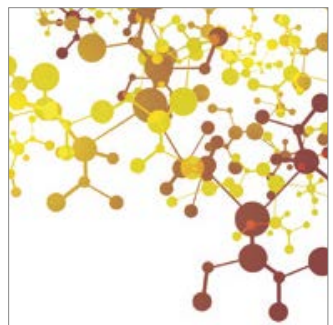

Applied Chemistry
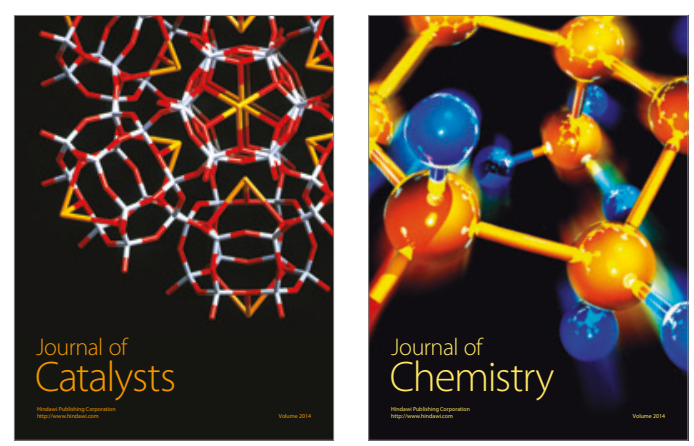
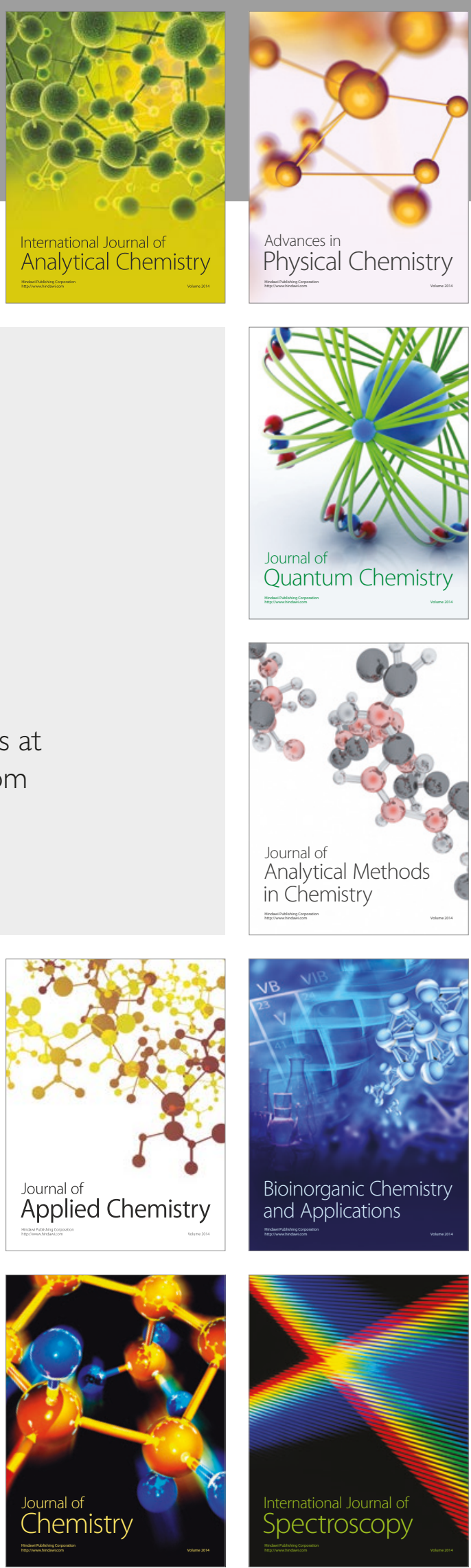